\title{
Evaluation of Growth and Yield Characters of Garden Pea Genotypes at Dailekh, Mid-Western Nepal
}

\author{
Binod Prasad Luitel ${ }^{{ }^{*}}$, Tul Bahadur Pun ${ }^{2}$ and Bishnu Bahadur Bhandari ${ }^{1}$ \\ ${ }^{1}$ Horticulture Research Station, Dailekh, Karnali Province \\ ${ }^{2}$ Mahalaxmi Nagarpalika-4, Lalitpur, Nepal \\ "Corresponding Author's Email: binodsan@yahoo.com \\ "Orcid ID: https://orcid.org/0000-0002-6958-4687
}

Received on: 13 September 2020, Revised on:26 January 2021, Accepted on: 22 March 2021

\begin{abstract}
Knowledge of phenotypic variation among the germplasm is important for the breeding program of garden pea. This study was conducted to evaluate the growth and yield traits of garden pea genotypes and to identify high yielding,and powdery mildew resistant genotype at Horticulture Research Station (HRS), Dailekh, Mid-western Nepal. Eleven garden pea genotypes were evaluated in the main production season (2018-2019) and compared with 'Sikkim Local' as standard variety, and the experiment was laid out in randomized complete block design with three replications. The analysis of variance revealed that genotypes had significant variation for all the traits studied except few insignificant traits. Significantly higher number of green pod/plant, green pod yield/ plant, seed number/pod and seed yield/plant were recorded in genotypes DGP-12-18-2 and DGP-12-18-1 as compared with other studied genotypes. Genotype DGP-12-18-2, and DGP-12-18-1 exhibited resistant (2) to powdery mildew disease and these genotypes showed $45.8 \%$ and $16.6 \%$ yield advantage over the standard check 'Sikkim Local' variety. Therefore, genotypes DGP-12-18-2 and DGP-12-18-1 can be recommended to produce for fresh green pod and seed yield at on-farm condition of Mid-Western Nepal.
\end{abstract}

Keywords: Breeding, genotypes,on-farm, phenotypic variation, pod yield

\section{Introduction:}

Pea is an important annual herbaceous legume belonging to the family Fabaceae which is the third largest family of flowering plants having more than 450 genera and over 1200 species. Pea (Pisum sativum L.) is one the world's oldest domesticated crops and the third most widely grown legume crop worldwide (Smykal et al., 2010). The six Pisum species reported so far are $P$. sativum L., $P$. arvense, $P$. elatius Stev., $P$. abyssinicum Braun, P. humileBoiss and Noe and P. fulvumSibth and Sm. Among them, cultivated Pisum is dominated by $P$. sativum but $P$. sativum ssp abyssinicum is an independently derived cultivated type. In Nepal, garden pea (P. sativum L.) is grown commonly in cool season for fresh green seeds, tender green pods, and dried seeds.

Garden pea is an important legume, widely grown in terai, mid-hills and high hills of Nepal. Green immature pod, immature seeds and dry seeds are mostly preferred by consumers and there is high demand of peas inmarket. Also, the tradition of making pickles using driedpeas seeds in household is increased its demand.In addition, it is a good source of protein, carbohydrates, vitamin $\mathrm{A}$, and $\mathrm{C}$, calcium, phosphorus (Ofga, 2019). This is an important vegetable crop to farmers for cash earning and it also contributes to cope the food and 
nutritional security of the people especially in hills of Nepal. Since pea is a cool season crop, it is grown in winter season in terai, autumn season in mid hills and summer season in hills (Poon et al., 2004). Besides its nutritional importance, pea being a legume crop; it enriches the soil by adding significant amounts of nitrogen through nitrogen fixing.

According to a report (MoALD, 2019), pea is cultivated in 8,275 ha of land with a total production $72,557 \mathrm{mt}$ and productivity of $8.7 \mathrm{t} / \mathrm{ha}$ in Nepal but in Karnali Province, it is limited in 512 ha, with total production of $4,333 \mathrm{mt}$ and the productivity of $8.4 \mathrm{t} / \mathrm{ha}$. Despite its importance, the average national productivity is very low than the yield potential of the cultivar.With increasing demand of fresh pod and dry seed, the present production couldn't meet the galloping demand of market. Lacking of high yielding, early maturing, powdery mildew resistant and quality preferably smooth seeded variety are the major limiting constraints of pea production in Nepal. Powdery mildew caused by Erysiphe pisiis one of the most destructive and widely prevalent diseases and this disease occur every year in Dailekh. This diseasereduces the yield and seed quality. Suneetha et al. (2014) reported 33 to $69 \%$ of pea foliage to be infected with powdery mildew. Yield losses up to $47 \%$ had been reported to powdery mildew by different researchers (Munjal et al., 1963; Nisar et al., 2006). Use of resistant cultivar reduce the use of chemicals and eliminates their negative effects (Chaudhary and Banyal, 2017).

HRS, Dailekh is a lead centre of pea research in Nepal and it has been collecting different pea varieties, developing breeding lines and genetic materials, and evaluating them particularly for high yield, early maturity, powdery mildew, and fusarium wilt since 2010 (ARS, 2014). Two varieties (Sikkim Local and Arkel) released in pea so far in Nepal are not addressed properly to grow in diverse environment as well as to meet the needs of farmers. In the past, several studies were carried out in order to evaluate plant and yield characters in pea genotypes in Nepal (Poon et al., 2004; Poudel et al., 2017; Lohani et al., 2017). However, study on the selection of high yielding with powdery mildew disease resistance in different pea breeding lines are not undertaken so far. Therefore, this study was designed to select high yielding and powdery mildew resistant pea genotypes at mid-western of hills of Nepal.

\section{Material and Methods:}

\section{Description of the experimental site}

The experiment was conducted at HRS, Dailekh which is located at $28^{\circ} 13^{\prime} 6.18^{\prime \prime} \mathrm{N}$ longitudesand $83^{\circ} 58^{\prime} 27.72^{\prime \prime} \mathrm{E}$ latitude with an elevation of $1,255 \mathrm{~m}$ asl. This station represents mid-western hills of Karnali Province and falls under sub-tropical climatic region. This district receivedan average annual rainfall of $26-150 \mathrm{~mm}$ (HRS, 2019) and June to September is the major rainy season. This district receives less annual rainfall as compared to other regions so it can be characterized as dry hill. The dominant soil type is clay loam with slight acidity. In 2018-2019, maximum temperature during the cropping season (Oct.-April) ranged from $18.4^{\circ} \mathrm{C}$ (Jan.) to $28.0^{\circ} \mathrm{C}$ (April) but in $2019-2020$, it ranged from $15.5^{\circ} \mathrm{C}$ (Jan.) to $27.6^{\circ} \mathrm{C}$ (April). Minimum temperature was the lowest in Jan.-Feb in both years but rainfall distribution was inconsistent in the both years (Fig. 1).

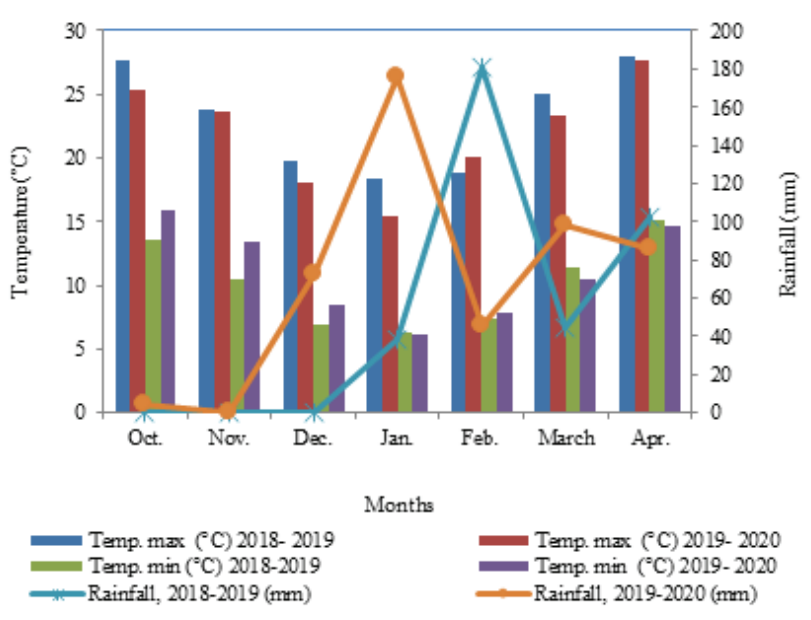

Figure 1. Monthly temperature and rainfall of cropping season (Oct.-April) of Garden pea at HRS, Dailekh during 2018-2019.

\section{Plant materials and experimental design}

Altogether, 40 garden pea genotypes developed from the crossing in 2012 and were evaluated as Preliminary Yield Trial (PYT) at HRS, Dailekh in 2016 and 2017 for powdery mildew and yield characters. Based on plant, powdery mildew and yield characters, 12 genotypes were selected in Coordinated Varietal Trial (CVT) to evaluate as on-station. Genotypes 13.04.14 (A-1), 14.4.14 (C-2) LGW, 37.05.1 (C-1)LYR, (2)1.3(A-2)RR, 18.05(C-2) LYW, 5.01.4(A-2) LGR, 39DCP-4(4.12B), 27.4.4(A1) $\mathrm{YW}, 22.05 .19(\mathrm{~A}), 40.1 .4(\mathrm{~A}-1) \mathrm{YR}, 36.8 .6(\mathrm{~B}-2) \mathrm{RR}$, and 25.6.5 (A)YR were selected and nomenclatured 
as DGP-12-18-1, DGP-12-18-2, DGP-12-18-3, DGP12-18-4, DGP-12-18-5, DGP-12-18-6, DGP-12-18-7, DGP-12-18-8, DGP-12-18-9, DGP-12-18-10, DGP12-18-11 and DGP-12-18-12, respectively. Where, DGP stands for 'Dailekh Garden Pea', 12 stands for crossing year '2012', 18 stands 'selection year ' and remaining '1, $2,3 \ldots$ ' stands 'the genotype number'. These 12 selected genotypes (indeterminate type) were further evaluated along with 'Sikkim Local' as a check variety for their plant, powdery mildew and yield at on-station during two years (Oct. 2018-April, 2019, and Oct. 2019-April, 2020). The experiment was laid out in randomized complete block design with three replications. Seeds were sown by hand in Oct. 10, 2018 and 2019 and the intra and inter row spacing were maintained at $10 \mathrm{~cm}$ and $75 \mathrm{~cm}$, respectively. Each plot contained 24 plants with each row had six plants. The space between plots within block was $50 \mathrm{~cm}$ and blocks within each replication was $1 \mathrm{~m}$. Fertilizer was applied at the rate of 30:40:40 $\mathrm{kg} / \mathrm{ha} \mathrm{NP}_{2} \mathrm{O}_{5} \mathrm{~K}_{2} \mathrm{O}$ and well-rotten farmyard manure was applied at the rate of $15 \mathrm{t} / \mathrm{ha}$. Half amount of nitrogen, full amount of phosphorus, potassium, and farmyard manure was applied at the land preparation time, and remaining half amount of nitrogen was given through urea as side dressing. Standard agronomic practices were followed in garden pea as recommended by Chalise and Pun (2015).

\section{Data collection and analysis}

Thirteen quantitative and three qualitative traits were measured in the studied genotypes. Two rows were used to recordthe data on green pod yield and remaining two rows were used to take dry pod yield. Days to $50 \%$ flowering was recorded when $50 \%$ of the plant population in each plot produce flower. The number of branch/plant was counted. Plant vigor was rated on 1-5 scale $(1=$ poor, and $5=$ Excellent). Plant height $(\mathrm{cm})$ was measured from the ground level to the top of the plant. Green pod was first harvested on March, $17^{\text {th }}$ for both years (2019 and 2020) and additional two harvests were done for green pod collection. The numbers of green pods and yieldwere recorded at commercial maturity stage from five randomly selected plants. The average length $(\mathrm{cm})$ and diameter of pod was measured at commercial maturity stage using scale and vernier caliper, respectively. For powdery mildew, the diseased area represents colonies on the upper surface of pea leaflets. Disease areas were drawn to cover $0,5,10$, $15,20,33,46,60,73,86$, and $100 \%$ of leaf surface which corresponds $0,1,2,3,4,5,6,7,8,9$ and 10 score (Fallon et al., 1995). In general, 0 represents highly resistant (no disease symptoms), 2 = resistant, 3 and $4=$ tolerant and above 5 was considered as susceptible to powdery mildew. Five readings were taken on March 26 $6^{\text {thin }}$ both years (2019 and 2020) at each plot for powdery mildew and averaged it. Dry pod was harvested first in April $10^{\text {th }}$ for both years (2019 and 2020) and two more additional harvests were done to complete the data.The number of seeds were counted for each pod of the five plants and averaged over the number of pods. The seed yield /plant (g) was measured on the five plants at physiological maturity. The weight of 100 seeds was selected randomly from five plants/ plot and averaged it. Seedyield (g) of each plant was measured on clean, dried seed and the measured seed yield value (g) was converted to ton/ha for analysis. Seed shape, surface and color were recorded based on visual observation. The experimental data were processed and analyzed using GenStat Release 10.3 DE Software (VSN International Ltd.). Correlation analysis(Pearson's correlation coefficient) of characters was done by IBM SPSS Statistics (Version 19). To find influence of genotypes on plant and yield characters, analysis of variance (ANOVA) and LSD test were used for any significant differences at the $\mathrm{P}<0.05$ level between the means.

\section{Results:}

\section{ANOVA on plant characters and green pod yield}

Genotypes had non-significant effect on days to $50 \%$ flowering and branch number/plantbut it affected significantly on plant vigor, plant height, green pod number/plant and green pod yield/plant (Table 1). The influence of year on days to $50 \%$ flowering and branch number/plant remained non-significant whereas it showed significantly different in plant vigor, plant height, and green pod/plant. The variation in temperature and rainfall during the cropping season might influence the plant vigor, plant height and pod number/plant. The interaction of genotype and year showed non-significant effect in all the studied traits except plant height. The average maximum temperature during crop growing period (October to April) in $2018-2019$ was $23.7^{\circ} \mathrm{C}$ whereas it was the lowest $\left(21.9^{\circ} \mathrm{C}\right)$ in $2019-2020$. In case of precipitation, it was highest $(68.8 \mathrm{~mm})$ in 2019 2020 but the lowest $(46.8 \mathrm{~mm})$ precipitation was noted in the year 2018-2019 and this might be attributed to cause the variation in plant height. 
Table 1. Mean square values of plant characters and green pod yield of pea genotypes for combined analysis of variance over two years (2018 to 2019).

\begin{tabular}{|l|c|c|c|c|c|c|c|}
\hline Source of variation & DF & DFFL & BPPNT & PVIG & PHT & GPP & GPYLD \\
\hline Genotypes $(G)$ & 12 & $105.47^{\text {ns }}$ & $1.08^{\text {ns }}$ & $2.55^{* *}$ & $2839.6^{* *}$ & $525.8^{*}$ & $14891.0^{* *}$ \\
\hline Year $(\mathrm{Y})$ & 1 & $10200.82^{\text {ns }}$ & $0.37^{\text {ns }}$ & $6.06^{* *}$ & $24977.7^{* *}$ & $867.6^{*}$ & $96.00^{\text {ns }}$ \\
\hline G x Y & 12 & $127.5^{\text {ns }}$ & $0.61^{\text {ns }}$ & $1.29^{\text {ns }}$ & $904.3^{*}$ & $86.4^{\text {ns }}$ & $1635.0^{\text {ns }}$ \\
\hline Error & 50 & 96.44 & 0.66 & 0.72 & 423.6 & 206.5 & 4624.0 \\
\hline
\end{tabular}

ns, $* * *$ non-significant or significant at $5 \%$ and $1 \%$, respectively. DF $=$ Degree of freedom, DFFL $=$ Days to $50 \%$ flowering, BPPNT $=$ Branch/plant (no.), PHT = Plant height $(\mathrm{cm}), \mathrm{PVIG}=$ Plant vigor $(1-5), \mathrm{GPP}=$ Green pod/plant (no.), and GPYLD = Green pod yield/plant (g)

\section{ANOVA on pod characters, powdery mildew disease and seed yield}

Genotypes affected significantly on pod length, powdery mildew, seed number/plant, seed yield/plant, hundred grain weight and seed yield/ha. Similarly, year revealed the significant variation in all the traits except pod length. In contrast, the interaction effect between genotypes and years was non-significant in all the characters studied (Table 2).

Table 2. Mean square values of pod characters, powdery mildew disease and seed yield of pea genotypes for combined analysis of variance over two years (2018 to 2019).

\begin{tabular}{|l|l|l|l|l|l|l|l|l|}
\hline Source of variation & DF & PL & PD & PM & SPP & SYPP & HSWT & SYLD \\
\hline Genotypes $(\mathrm{G})$ & 12 & $7.95^{* *}$ & $8.50^{\mathrm{ns}}$ & $8.06^{* *}$ & $4.08^{* *}$ & $800.0^{* *}$ & $73.28^{* *}$ & $2.893^{* *}$ \\
\hline Year $(\mathrm{Y})$ & 1 & $0.15^{\mathrm{ns}}$ & $162.21^{* *}$ & $50.88^{* *}$ & $4.60^{*}$ & $2421.3^{* *}$ & $135.92^{* *}$ & $24.07^{* *}$ \\
\hline G x Y & 12 & $1.04^{\mathrm{ns}}$ & $7.22^{\mathrm{ns}}$ & $1.92^{\mathrm{ns}}$ & $1.05^{\mathrm{ns}}$ & $148.0^{\mathrm{ns}}$ & $15.26^{\mathrm{ns}}$ & $0.57^{\mathrm{ns}}$ \\
\hline Error & 50 & 1.09 & 11.24 & 2.03 & 1.09 & 299.8 & 14.45 & 1.115 \\
\hline
\end{tabular}

$\mathrm{ns}, * * *$ non-significant or significant at $5 \%$ and $1 \%$, respectively. $\mathrm{DF}=$ Degree of freedom, $\mathrm{PL}=$ Pod length $(\mathrm{cm})$, $\mathrm{PD}=$ Pod diameter $(\mathrm{mm})$, Powdery mildew (1-10 score), SPP = Seed/pod (no.), SYPP = Seed yield/plant $(\mathrm{g})$, HGWT $=$ hundred seed weight $(\mathrm{g})$, and SYLD $=$ Seed yield $(\mathrm{t} / \mathrm{ha})$.

\section{Mean performance of genotypes for plant and green} pod yield characters

The combined mean over two years on plant and yield characters of pea genotypes are given in Table 3. Genotypes did not show any significant differences in days to $50 \%$ flowering and branch number/plant. But plant vigor was highly significantly different among the genotypes. Genotype DGP-12-18-1, DGP-12-182 and Sikkim Local showed the highest (4) in plant vigor whereas the lowest (2) plant vigor was observed in genotype DGP-12-18-3, DGP-12-18-3 and DGP-12-
18-8. The tallest plants were measured in Sikkim Local (200.9 cm) followed by genotype DGP-12-18-7 (179.6 $\mathrm{cm})$ but it was the lowest $(127.9 \mathrm{~cm})$ in genotype DGP12-18-4. The number of green pod/plant showed the significant differences among the genotypes. Genotype DGP-12-18-2 produced the maximum (49.0) number of green pod/plant followed by DGP-12-18-1 (47.0) and DGP-12-18-7 (42.0). Green pod yield/plant produced the highest $(240.5 \mathrm{~g})$ in DGP-12-18-2 followed by DGP-12-18-1 (219.0 g) but it was the lowest (64.6 g) in genotype DGP-12-18-4. 
Table 3. Means of genotypes over plant and yield characters pea genotypes for combined analysis of variance over two years (2018 to 2019).

\begin{tabular}{|l|c|c|c|c|c|c|}
\hline \multicolumn{1}{|c|}{ Pea genotypes } & DFFL & BPPNT & PVIG & PHT & GPP & GPYLD \\
\hline DGP-12-18-1 & 80.0 & 3.0 & 4.0 & 168.3 & 47.0 & 219.0 \\
\hline DGP-12-18-2 & 77.0 & 4.0 & 4.0 & 159.4 & 49.0 & 240.5 \\
\hline DGP-12-18-3 & 85.0 & 2.0 & 2.0 & 130.4 & 23.0 & 124.9 \\
\hline DGP-12-18-4 & 80.0 & 3.0 & 2.0 & 127.9 & 20.0 & 64.6 \\
\hline DGP-12-18-5 & 85.0 & 3.0 & 3.0 & 142.0 & 26.0 & 128.3 \\
\hline DGP-12-18-6 & 69.0 & 3.0 & 3.0 & 132.6 & 25.0 & 119.7 \\
\hline DGP-12-18-7 & 75.0 & 3.0 & 3.0 & 179.6 & 42.0 & 124.6 \\
\hline DGP-12-18-8 & 80.0 & 3.0 & 2.0 & 149.2 & 26.0 & 96.1 \\
\hline DGP-12-18-9 & 81.0 & 3.0 & 3.0 & 163.5 & 38.0 & 162.3 \\
\hline DGP-12-18-10 & 82.0 & 3.0 & 3.0 & 132.6 & 29.0 & 103.4 \\
\hline DGP-12-18-11 & 77.0 & 3.0 & 3.0 & 167.0 & 31.0 & 152.8 \\
\hline DGP-12-18-12 & 80.0 & 2.0 & 3.0 & 150.9 & 29.0 & 92.7 \\
\hline Sikkim Local (Check) & 82.0 & 3.0 & 4.0 & 200.9 & 37.0 & 165.3 \\
\hline Mean & 79.4 & 3.0 & 3.05 & 154.2 & 32.5 & 138.0 \\
\hline P Value & 0.386 & 0.109 & $<0.001$ & 0.001 & $<0.010$ & 0.002 \\
\hline LSD (0.05) & 11.39 & 0.94 & 0.99 & 23.87 & 16.66 & 78.85 \\
\hline CV (\%) & 12.4 & 26.1 & 28.0 & 13.3 & 34.3 & 39.3 \\
\hline
\end{tabular}

$\mathrm{DFFL}=$ Days to $50 \%$ flowering, $\mathrm{BPPNT}=\mathrm{Branch} / \mathrm{plant}($ no. $), \mathrm{PHT}=$ Plant height $(\mathrm{cm}), \mathrm{PVIG}=$ Plant vigor $(1-5)$, $\mathrm{GPP}=$ Green pod/plant (no.), and GPYLD $=$ Green pod yield/plant $(\mathrm{g})$

Mean performance of genotypes for pod characters, powdery mildew disease and seed yield

The pod length was varied from $7.6 \mathrm{~cm}$ (DGP-1218-4) to $10.9 \mathrm{~cm}$ (DGP-12-18-1) with the average of $9.28 \mathrm{~cm}$. Pod diameter was non-significant among the genotypes. Powdery mildew disease was significantly varied among the tested genotypes. Genotypes DGP12-18-1, DGP-12-18-2, and DGP-12-18-9 showed the resistant (2.0) to powdery mildew disease whereas DGP-12-18-7 (3.0), DGP-12-18-11 (3.0), Sikkim Local (3.0), DPG-12-18-3 (4.0), DGP-12-18-5 (4.0), and DGP-12-18-8 (4.0) revealed the tolerance to powdery mildew (Table 4). The number of seed/pod was ranged from 5.0 to 7.0 with the average of 6.42 . With respect of seed yield/plant, it produced the highest $(57.2 \mathrm{~g})$ in DGP-12-18-2 which was statistically at par with DGP-
12-18-1 (45.6 g), DGP-12-18-11 (44.2 g), DGP-1218-9 (40.4 g) and Sikkim Local (39.6 g) but DGP12$18-8$ produced the lowest $(15.1 \mathrm{~g})$ seed yield/plant. The hundred seed weight also exhibited the significant differences among the genotypes. Sikkim Local gave the highest hundred seed weight ( $31.3 \mathrm{~g}$ ) followed by DGP-12-18-11 (28.7 g) and DGP-12-18-1 (27.1 g) and the lowest $(18.0 \mathrm{~g})$ was produced in genotype DGP-1218-7. As for seed yield, it was produced the highest (3.5 t/ha) in DGP-12-18-2 which was statistically similar to DGP-12-18-1 (2.8 t/ha), DGP-12-18-9 (2.4 t/ha) and Sikkim Local (2.4 t/ha). Seed shape was varied from elliptic to rhomboid and except the genotype DGP-1218-8, all the genotypes contained smooth seed surface. Seed color was varied from cream yellow, light green, yellow green to brown in the studied genotypes (Table 4). 
Table 4. Means of genotypes over pod characters, powdery mildew disease, and dry pod yield of pea genotypes and seed characters for combined analysis of variance over two years (2018 to 2019)

\begin{tabular}{|l|c|c|c|c|c|c|c|c|c|c|}
\hline \multicolumn{1}{|c|}{ Pea genotypes } & PL & PD & PM & SPP & SYPP & HSWT & SYLD & SSH & SS & SC \\
\hline DGP-12-18-1 & 10.9 & 15.6 & 2.0 & 7.0 & 45.6 & 27.1 & 2.8 & E & S & CY \\
\hline DGP-12-18-2 & 10.6 & 13.3 & 2.0 & 7.0 & 57.2 & 25.2 & 3.5 & E & S & LG \\
\hline DGP-12-18-3 & 9.8 & 13.9 & 4.0 & 7.0 & 28.5 & 24.3 & 1.8 & E & S & YG \\
\hline DGP-12-18-4 & 7.6 & 11.6 & 5.0 & 7.0 & 26.1 & 22.3 & 1.6 & Rh & S & B \\
\hline DGP-12-18-5 & 10.8 & 15.2 & 4.0 & 7.0 & 29.3 & 22.2 & 1.8 & E & S & LG \\
\hline DGP-12-18-6 & 9.2 & 13.5 & 6.0 & 6.0 & 21.5 & 24.7 & 1.3 & E & S & LG \\
\hline DGP-12-18-7 & 7.9 & 11.9 & 3.0 & 6.0 & 30.8 & 18.0 & 1.8 & E & S & LG \\
\hline DGP-12-18-8 & 9.4 & 13.7 & 4.0 & 5.0 & 15.1 & 21.4 & 0.9 & Rh & R & LG \\
\hline DGP-12-18-9 & 8.8 & 12.4 & 2.0 & 7.0 & 40.4 & 22.0 & 2.4 & E & S & CY \\
\hline DGP-12-18-10 & 9.6 & 13.2 & 5.0 & 6.0 & 24.7 & 21.4 & 1.5 & E & S & CY \\
\hline DGP-12-18-11 & 10.1 & 14.2 & 3.0 & 7.0 & 44.2 & 28.7 & 2.7 & E & S & B \\
\hline DGP-12-18-12 & 8.4 & 13.1 & 4.0 & 5.0 & 28.4 & 23.9 & 1.7 & E & S & CY \\
\hline Sikkim Local (Check) & 7.8 & 12.1 & 3.0 & 5.0 & 39.6 & 31.3 & 2.4 & E & S & LG \\
\hline Mean & 9.28 & 13.35 & 3.86 & 6.42 & 33.2 & 24.04 & 2.03 & & & \\
\hline P Value & $<0.001$ & 0.691 & $<0.001$ & $<0.001$ & 0.008 & $<0.001$ & 0.009 & & & \\
\hline LSD (0.05) & 1.215 & 3.88 & 1.65 & 1.212 & 20.08 & 4.40 & 1.22 & & & \\
\hline CV (\%) & 11.3 & 25.1 & 36.9 & 16.3 & 32.2 & 15.8 & 32.1 & & & \\
\hline
\end{tabular}

$\mathrm{PL}=$ Pod length $(\mathrm{cm}), \mathrm{PD}=$ Pod diameter $(\mathrm{mm})$, Powdery mildew (1-10 score), SPP = Seed/pod (no.), SYPP $=$ Seed yield/plant $(\mathrm{g}), \mathrm{HSWT}=$ Hundred seed weight $(\mathrm{g})$, and $\mathrm{SYLD}=$ Seed yield $(\mathrm{t} / \mathrm{ha}), \mathrm{SSH}=$ Seed shape; E = Elliptical, $\mathrm{Rh}=$ Rhomboid, $\mathrm{SS}=$ Seed surface; $\mathrm{S}=$ smooth, $\mathrm{R}=$ Rough; $\mathrm{SC}=$ Seed color, $\mathrm{CY}=$ Cream yellow; $\mathrm{LG}=$ light green; $\mathrm{YG}=$ Yellow green, $\mathrm{B}=$ Brown,

\section{Correlation among the plant and yield characters}

The simple correlation of phenotypic traits among garden pea genotypes is presented Table 5. Days to $50 \%$ flowering showed weak negative correlation with green pod yield/plant and moderate significant negative correlation with seed yield/ha. There was a significant positive weak correlationwithseed yield/ plant,seed yield/ha with branch number/plant. Plant vigor had a weak significant positive correlation with green pod/plant, green pod yield/plant, seed yield/ plant and seed yield/ha. But the plant height showed the moderate significant positive association with green pod number/plant, seed yield/plant and seed yield/ha.
The number green pod/plant had a strong significant positive correlation with green pod yield/plant and it showed the positive significant association with seed yield/plant and seed yield/ha. Similarly, significant positive phenotypic correlation between green pod yield/plant and seed yield. The number of seed/pod had a significant positive correlation with seed yield/plant and seed yield/ha. The strong and significant positive correlation was observed between seed yield/plant and seed yield/ha. But hundred seed weight exhibited weak phenotypic correlation with seed yield. 
Table 5. Pearson's correlation coefficient analysis among phenotypic traits of pea genotypes during $2018-2019$ at HRS, Dailekh

\begin{tabular}{|l|l|l|l|l|l|l|l|l|l|l|l|l|l|}
\hline Variables & DFFL & BRNPP & PVIG & PHT & GPPT & GPYLD & PL & PD & PM & SPP & SYPP & HSWT & SYLD \\
\hline DFFL & 1.0 & -.05 & $.25^{*}$ & $-.44^{* *}$ & .03 & $.37^{* *}$ & -.13 & .01 & $-.27^{*}$ & $.25^{*}$ & $-.31^{* *}$ & -.17 & $-.42^{* *}$ \\
\hline BRNPP & & 1.0 & $.42^{* *}$ & 0.12 & 0.21 & $.28^{*}$ & .07 & .01 & -.17 & .12 & $.36^{* *}$ & .09 & $.31^{* *}$ \\
\hline PVIG & & & 1.0 & .21 & $.34^{* *}$ & $.38^{* *}$ & .05 & .15 & -.12 & -.01 & $.38^{* *}$ & .18 & $.29^{* *}$ \\
\hline PHT & & & & 1.0 & $.40^{* *}$ & $.27^{*}$ & -.09 & $-.29^{* *}$ & -.06 & $-.24^{*}$ & $.45^{* *}$ & $.34^{* *}$ & $.51^{* *}$ \\
\hline GPPT & & & & & 1.0 & $.84^{* *}$ & .08 & -.01 & -.10 & $.22^{*}$ & $.57^{* *}$ & $.25^{*}$ & $.54^{* *}$ \\
\hline GPYLD & & & & & & 1.0 & $.27^{*}$ & .14 & -.15 & $.26^{*}$ & $.53^{* *}$ & $.35^{* *}$ & $.46^{* *}$ \\
\hline PL & & & & & & & 1.0 & $.35^{* *}$ & -.01 & $.43^{* *}$ & .13 & .09 & .14 \\
\hline PD & & & & & & & & 1.0 & $-.26^{*}$ & $.30^{*}$ & .04 & -.12 & -.08 \\
\hline PM & & & & & & & & & 1.0 & -.16 & -.10 & .15 & -.03 \\
\hline SPP & & & & & & & & & & 1.0 & $.48^{* *}$ & -.13 & $.58^{* *}$ \\
\hline SYPP & & & & & & & & & & & 1.0 & $.33^{* *}$ & $.98^{* *}$ \\
\hline HSWT & & & & & & & & & & & & 1.0 & $.35^{* *}$ \\
\hline SYLD & & & & & & & & & & & & & 1.0 \\
\hline
\end{tabular}

$*$ and $* *$ significant at $5 \%$ and $1 \%$, respectively. DFFT: Days to 50\% flowering; ); BRNPP: Branch/plant (no.); PVIG: Plant vigor (1-5 score); PHT: Plant height (cm); GPPT : Green pod/plant (no.); GPYLD: Green pod yield/ plant (g); PL: Pod length (cm); PD : Pod diameter, PM: Powdery mildew; SPP: Seed/pod (no.); SYPP: Seed yield/ plant (g); HSWT: Hundred seed weight (g); and SYLD: Seed yield (t/ha)

\section{Discussion:}

In this study, garden pea genotypes showed the significant phenotypic variability for phenology and yield attributes. Except days to 50 percent flowering and branch number/plant, genotypes showed significant differences for plant characters and green pod yield. The genotypic difference in the plant and yield characters indicates the presence of variability for each trait which was also reported by Ofga (2019). Khan et al. (2013) had also reported the variation in plant characters in pea genotypes under rain-fed condition. The mean square due to genotype was significant in green pod number/ plant. The number of pod/plant is a variable trait and this result is in agreement with the results of Lakic et al. (2017).Genotypes showed the significant variation in green pod yield/plant which indicates differential response of genotypes of this character. Similar results were reported by previous researchers (Chadha et al., 2010; Khichi et al., 2017; Poudel et al, 2017). In the study of Ei-dakkak (2016), he reported the maximum $(215.3 \mathrm{~g})$ green pod yield/plant in genotype of pea but our study showed that the maximum $(240.5 \mathrm{~g})$ green pod yield/plant. The significant effect of year on plant vigor, plant height, green pod number/plant and green pod yield/plant due to environmental fluctuation particularly temperature and rainfall during the cropping season. The average maximum temperature during crop growing period (October-April) in 20182019 was $23.7^{\circ} \mathrm{C}$ but it was lowest $\left(21.9^{\circ} \mathrm{C}\right)$ in the cropping season of 2019-2020. In contrast, amount rainfall distribution was higher $(68.8 \mathrm{~mm})$ in 2019 2020 than the cropping season of 2018-2020 (46.8 mm) (Fig. 1). The differences in temperature and uneven distribution of rainfall during the cropping season in both years might be influenced the plant and yield traits. The significant interaction between genotype and year on plant height might also be due to environmental condition that affected genetic make-up of the cultivars.

Genotypes also affected the pod size particularly on pod length. Pod size is a varietal character but it is also affected by vigor of the plant (Bozoglu et al., 2007) but our study showed the contradictory result in this variable. Powdery mildew is one of major fungal disease that has deleterious effect on yield of pea crops (Fallon et al, 1990). In our study, powdery mildew above five score showed the susceptibility to powdery mildew and most of the genotypes were tolerant to powdery mildew. Identification of resistant cultivars again powdery mildew in pea genotypes was also studied by previous researchers (Falloon et al., 1995; Xue et 
al., 2004; Chaudhary and Banyal, 2017). Number of seed/pod is the important yield attributing characters and this showed highly significant differences among the pea genotypes. In the study of Poudel et al. (2017), they reported 6 to 8 seeds/pod which is much close to this finding.Choudhary and Sharma (2004) had also reported the similar findings in the study of pea cultivars. This study reported the maximum $(57.2 \mathrm{~g})$ seed yield/plant in DGP-12-18-2 but in the study of Bairwa et al. (2018), they reported the maximum (67.0 g) seed/plant in P-89 pea genotype. Khichi et al. (2017) reported the greatest $(59.2 \mathrm{~g})$ seed yield/plant in pea genotypes which is close to our result. Variation in seed yield/plant among the pea genotypes were also reported by many researchers (Orak and Nizam, 2009; Bairwa et al., 2018). Genotypes showed highly significant differences in 100 seed weight and this could be due to the genetic makeup the variety. Genotype DGP-1218-2 produced the highest ( $3.5 \mathrm{t} / \mathrm{ha})$ seed yield. Good plant vigor, more number of green pod/plant, green pod yield/plant, good pod size, more number of seed/ pod, more seed yield/plant might be attributed for high yield particularly in this genotype. Significant effect of year was noticed in pod size, powdery mildew, seed number/plant, seed yield/plant, 100 seed weight and seed yield/ha which might be due to climatic condition like temperature and rainfall. Seed morphology namely seed shape, color and surface also influences consumer's preferences (personal communication) and generally, these traits depends on genetic make of the cultivar. Phenotypic variation observed in seed of studied pea genotypes helps to study physicochemical properties. Santos et al. (2019) had used seed morphological traits of pea genotypes particularly seed shape, color and surface for the study of physicochemical functional properties.

The association study of yield with plant and yield characters indicated that there was a significant positive correlation of seed yield/ha with plant height, green pod number/plant, green pod yield/plant, seed number/pod, and seed yield/plant. More number of branch/plant, higher number of green pod/plant and number of seed/ plant ultimately contributing positively towards yield. In the study of Singh and Singh (1989), 100 seed weight was negatively associated with grain yield but in our study it showed the weak correlation with seed yield. In the study of Ofga (2019), he reported the significant positive phenotypic correlation of 100 seed weight with seed yield. Thus, significant positive correlation between seed yield and number of characters namely plant height, green pod number/plant, green pod yield/ plant, seed number/pod and seed yield/plant indicating that selection for any one of the traits allows toimprove seed yield of pea genotypes.

\section{Conclusion:}

Genotypes exhibited the significant variation for plant and yield characters which are useful for pea breeding program. The genotype DGP-12-18-2 and DGP-12-8-1 showed the resistant to powdery mildew, and high green pod and seed yield. Plant height, green pod number/ plant, green pod yield/plant, seed number/plant, and seed yield/plant showed significant positive correlation with seed yield/ha which indicates the selection of these traits can be used as selection criteria to improve the seed yield of pea cultivars. The candidate genotype DGP-12-18-2 and DGP-12-18-1 had 45.8 and 16.7\% yield advantage over the standard checks and hence, these two genotypes can be recommended to grow fresh and seed production at mid-western of Nepal.

\section{Acknowledgements:}

This research was supported by NARC (Project No. 327) under project titled 'Varietal Development of Vegetable Crops at Mid-Hills of Karnali Province'. Authors are also thankful to field staffs of HRS, Dailekh for their hard-working during the entire period of experimentation.

\section{Declaration of conflict of interest and ethical approval:}

The authors declare no conflict of interest.

\section{References:}

ARS (2014). Annual Report 2070/71 (2013/2014). Agricultural Research Station (Horticulture), NARC, Kimugaon, Dailekh, Nepal

Bairwa, D.S., Rana, D. K., Kumar,P.,Kumar,S., Bhati,V. \& Parihar,D. (2018). Response of pea Varieties on Growth, Yield Attributes and Quality under Valley Conditions. IJAEB, 11(3), 585-588.

Bozoglu, H., Peksen,E., Peksen,A. \& Gulumser, A. (2007). Determination of the yield performance and harvesting period of fifteen pea (Pisum 
sativum L.) cultivars sown in autumn and spring. P. J. Bot., 39(6), 2017-2025.

Chadha, S., Sharma,A. \& Paul,Y.S. (2010). Performance of different pea genotypes under organic farming ecosystem. Himalchal J. Agric. Res., 36, 241242.

Chalise, B. \& Pun,T.B.(2015). Nepalma Kheki Garine MukhyaTarkariBaliharuko Biu UtpadhanPrabidhi (Nepali Version). Nepal Agricultural Research Council, Horticulture Research Station, Kimugaon, Dailekh.

Chaudhary, J., \&Banyal,D.K. (2017). Evaluation of pea genotypes for resistance against powderymildew caused by Erysiphe pisi. Indian Phytopath., 70 (1), 69-74.

Choudhary, D.K. \&Sharma, R.R. (2004). Correlation and path analysis of F1 and F2 generation of garden pea. In: Agricultural Research for Enhancing livelihood of Nepalese People (BK Joshi, SL Joshi, and KP Paudyal, eds). Proc. $2^{\text {nd }}$ SAS-N convention, 30 July-1 Aug 2003, Kathmandu, pp. 204-206.

Ei-dakkak, A.A.A. (2016). Genetic improvement for yield and quality characters in pea by using selection. J. Plant Production, 7 (8), 837 - 842.

Falloon, R.E., Viljanen-Rollinson,S.L.H., Coles,G.D. \&Poff,J.D. (1995). Disease severity keys for powdery and downy mildews of pea, and powdery scab of potato. New Zealand Journal of Crop and Horticultural Science, 23, 31-37.

HRS (2019). Annual Report 2075/76 (2018/2019). (Ed. Binod Prasad Luitel), Horticulture Research Station, NARC, Kimugaun, Dailekh, Nepal.

Khan, T.N., Ramzan,A., Jillani, G., \&Mehamood,T. (2013). Morphological performance of peas (Pisum sativum L.) genotypes under rain-fed conditions of Potowar Region. J. Agric, Res., 51 (10), 51-60

Khichi, P., Pant,R.,\&Upadhayay,S. (2017). Performance of garden pea varieties for their growth and yield characters in Vidharbha region of Maharasthtra,
India. Journal of Applied and Natural Science, 9 (4), 2300-2304.

Lakic, Z., Stankovic, S.,Pavlovic,S.,Krnjajic,S. \&Popovic,V. (2017). Genetic variability in quantitative traits of field pea (Pisum sativum L.) genotypes. Czech J. Genet. Plant Breed., https:// doi.org/10.17221/89/2017-CJGPB.

Lohani, S., Choudhary, J. N.,Pun, A.B.,Deo, M.L.,Shrestha, S.L. \&Bhandari, B.B. (2017). Evaluation of yield attributing characters of garden pea (Pisum sativum L.) at Horticultural Research Station, Dailekh, Nepal. Gautam, IP, Shrestha, SL, Subedi, GD, Bhattarai, DR, Gotame, TP, Upadhyay, KP (Eds). Proceedings of the Ninth National Horticulture Workshop, May 31-June 1, 2017 (Jestha 17-18, 2074), NARC, HRD, Khumaltar, Lalitpur, Nepal.

MoALD (2019). Statistical information on Nepalese Agriculture 2018/19 (2075/76). Ministry of Agriculture and Livestock Development, Singhadurbar, Kathmandu, Nepal.

Munjal, R.L., Chenulu,V.V.\&Hora,T.S. (1963). Assessment oflosses due to powdery mildew (Erysiphe polygoni) on pea.Indian Phytopath., $16,268-270$.

Nisar, M., Ghafoor, A., Khan, M.R. \& Qureshi, A.S. (2006). Screening of Pisum sativum germplasm against Erysiphe pisisyd. Acta. Biol. Cracov. Bot., 48, 33-37.

Ofga, B.(2019). Comparing yield performance and morpho-agronomic characters of landraces and released varieties of field pea (Pisum sativum L.) at Agarfa and Goro Woredas, Bale Zone, Oromia Region, Ethiopia. International Journal of Genetics and Genomics, 7(3), 34-49.

Orak, A. \&Nizam,I. (2009). Genotype environment interaction and stability analysis of some Narbonne vetch (Vicia narbonensisL.) genotypes. Agric Aci. Tech., 1(4),108-112. 
Poon, T.B., Regmi, H.N.,Pokhrel, B.B., Oli, O.B. \&Sharma, S.R. (2004). Potential of promising varieties of garden pea in relation to determinate characters, the efficiency of green pod yield and monetary returns under the mid-hills environments of Dailekh. In: Agricultural Research for Enhancing Livlihood of Nepalese People (BK Joshi, SL Joshi and KP Paudyal, eds). Proc. $2^{\text {nd }}$ SAD-N Convention, 30 July-1 Aug 2003, Kathmandu, pp. 111-114.

Poudel, K., Karkee,A.,Shah,M.K. \&Karki,S. (2017). Performance of garden pea genotypes in eastern hills of Nepal. Journal of Nepal Agricultural Research Council, 3, 15-18.

Santos, C.S., Carbas, B., Castanho, A.,Vasconcelos, M.W.,Vaz Patto, M. C.,Domoney, C. \& Brites C. (2019). Variation in pea (Pisum sativum L.) seed quality traits defined by physical functional properties. Food, 8,57, doi: 10.3390/ foods 8110570

Singh, V. \&Singh, F. (1989). Selection criteria for yield in chickpea (Cicer Arietinum L.). Ind. J. Agri. Sci.,59, 32-35.

Smykal, P., Kenicer, G.,Flavell,A. J.,Corander, J.,Kosterin,O., Redden, R.J.,Ford,R.,Coyne,C.J.,
Maxted,N.I.,Ambrose,M.J.\&Ellis,N.T.H.(2011). Phylogeny, phylogeography and geneticdiversity of the Pisum genus. Plant Genetic Resources: Characterization and Utilization, 9 (1), 4-18.

Suneetha, T.B., Gopinath,S.M.\&Naik,S.L. (2014). Identificationof Resistance Gene Analogs (RGAs) linked to PowderyMildew Resistance in Peas. Int. J. Innov. Res. Adv. Eng., 6, 33-36.

Xue, A.G., Dyck,B.S. \&Warkentin,T.D. (2004). Evaluation of components of resistance to powdery mildew in field pea. Can. J. Plant Sci., 84 (4), 1183-1187. 